\title{
The Time Series Dynamics of Foreign Direct Investment and Economic Development
}

\begin{abstract}
Yi Zhang
ABSTRACT

The relationship between FDI inflows and economic growth has received immense attention among policy makers and business leaders but no consensus has been reached. By using Engle-Granger (1987) bivariate cointegration procedure, this paper analyzes the impact from FDI inflows to GDP as well as the causality between these two with the time series data from 1966 to 2005 for 5 countries. The results reveal that the growth effect of FDI inflows is still ambiguous for the 5 countries, while all of these countries have a significant effect from GDP on FDI inflows.
\end{abstract}

\section{INTRODUCTION}

During the past one decade, with the rapid growth and development of the world economy, the foreign direct investment (FDI) flows also have experienced a massive increase around the world. This foreign direct investment is defined as investment made to acquire lasting interest in enterprises operating outside of the economy of the investor ${ }^{1}$. According to the statistics from World Bank (2008), the global FDI flows increased from about US\$198.4 billion in 1990 to US\$1.47 trillion in 2007. Among the amount, the FDI inflows, a particular form of inward investment when foreign capital is invested in local resources, occupied a primary status and role. On the premise of such enhancement of both economic growth and FDI inflows, many people in most countries generally believe that FDI inflows strongly have a positively effect on the economic growth and development of their countries. For the host countries who introduce the FDI inflows, it is believed that the FDI inflows have many benefits for their countries' development. For example, it could invent additional capital, increase the employment rate of the host country. Also, FDI inflows could bring them new technology, skills, management experience, etc. So nowadays, in order to attract more FDI into the host countries, both developed and developing countries compete with each other by offering several incentives and carrying out various inviting strategies such as tax reduction, some preferential policies in particular area, etc. For instance, Finland put forward the idea of cutting corporate taxes from $29 \%$ to $26 \%$, which were critical to competing with FDI-hungry Estonia (Financial Times 15/16 2004: 4). In 2001, China removed the restrictions that solely foreign-owned enterprises were not permitted to invest in China unless they had advanced technology and equipment or exported mostly their product, leading to encourage foreignowned enterprises to introduce advanced technology and increase their export volume. China also carried out the policies of Develop China's West at Full Blast and Strategy of Reviving Rusty Industrial Bases to attract foreign-owned enterprises to invest into the western and northeastern regions of China. In Korea, FDI inflows began to be encouraged following the 1984 Foreign Capital Inducement Law which increased the number of manufacturing industries open to foreign direct investment (Sören Eriksson, 2005).

\footnotetext{
${ }^{1}$ Foreign Direct Investment, United Nations Conference on Trade and Development, www.unctad.org
} 
So is it true that FDI inflows will strongly promote the economic growth? In order to find the answer, many economists and scholars in the past engaged in exploring the relationship between FDI inflows and economic growth by using empirical data analysis. However, surprisingly, the findings from them were ambiguous.

The existing literature indicates that the FDI inflows truly has a strongly positive impact on the economic growth and development which are generally believed by most people. By working on the data of China, Zhang and Honglin (1999) provide evidence that the FDI inflows enhance China's economic growth. With the data of China's 28 provinces, Yao and SJ (2006) show that FDI has a strong and positive effect on economic growth. Trevino and Upadhyaya (2003) document that foreign direct investment have positively contributed to economic growth by using the panel data of India, Indonesia, Nepal, the Philippines and Thailand from 1990 to 1999. Using a panel of 119 developing countries, Basu, Guariglia (2007) observe that FDI promotes the economic growth. From the evidence of a panel of European transition countries from 1990 to 2003, Asteriou, Dassoiu, Glycopantis and Spoudai (2005) show that planned foreign investments have a positive and significant effect on the economic growth of these economies. The significantly positive result also come from Whalley and Xin (2006), Trevino and Upadhyaya (2003), Vu, Gangnes and Noy (2008).

In contrast to the above mentioned authors, a number of authors also indicate that the impact from the FDI inflows on the economic growth is negative. By using cross-sectional data for 75 developing countries from 1970-1980, Saltz (1992) suggest that countries which have had a larger presence of foreign direct investment (FDI) have had slower rates of economic growth than expected. The empirical results from Cave (1996) and Zhang (2001) are consistent with Saltz.

Still, some scholars, for example, Naveed and Shabbir (2006) obtain insignificant results about the growth effect of FDI. They use the data from 1971-2000 for 23 developed countries and conclude that FDI appears to be insignificant for the economic growth. Zhao and Du (2007) employ the data from 1985 to 2003 for China and find that the result is not significant. The same result also comes from Alexiou, Tsaliki, and Zagreb (2007) whose empirical findings cast serious doubts on the FDI-led growth hypothesis permeating the existing academic literature.

In recently years, a number of papers also appear to propose that the relationship between FDI inflows and economic growth might be dependent on some specific factors or variables. Such factors could include the financial system, educational level, the degree of openness, social stability, human capital value, technology, etc.

Alfaro, Chanda and Kalemli-Ozcan (2004) consider the role of financial markets for the relationship. Using cross-country data from 1975 to 1995, they conduct a regression of the growth of real per capita GDP in constant dollars on net FDI inflows adding finance variables to test the role of FDI on growth conditional on financial markets. Their results show that countries with well-developed financial markets gain significantly from FDI.

Ford, Rork and Elmslie (2008) suggest that FDI has a greater impact on per capita output growth than domestic investment for US states that meet a minimum human capital threshold. The authors employ the data of the 48 contiguous states from 1978-97 and take the per capital GDP growth as the dependent variable and FDI as the main independent variable. By adding the variable of COLLEGE, the measures of human capital, and its interaction with FDI variable 
(measured as a stock) ${ }^{2}$, - FDI*COLLEGE, the authors find that a minimum level of human capital is necessary for FDI to contribute more to growth than domestic investment.

Dhakal, Rahman and Upadhyaya (2007) analyze the FDI-growth nexus by using the data from 1980 to 1999 for nine Asian countries. The authors focus on institutional variables to explain the cross-country variation. They conclude that the positive effect from FDI inflows to economic growth would be enhanced by greater trade openness, more rule of law in the host country.

By using a panel data at the provincial level in China, Luo (2007) find that FDI has an insignificant effect on economic growth, nonetheless, through improving technical efficiency and "crowding" in domestic investment, FDI produce positive effects on China's economy.

There is a recent article entitled "Does Foreign Direct Investment Accelerate Economic Growth?" by Carkovic and Levine (2002). The authors do not find any impact of FDI inflows on the economic growth, nor does it rely on the factors such as human capital threshold or trade openness by using the data from 1960 to 1995 for 72 countries. Therefore, in the authors' opinion, policies such as reducing the taxation may not be beneficial for the host country.

In summary, there is no consensus on the FDI-GDP relationship according to the analysis of the previous studies. Despite the inconclusive research results, the notion that FDI inflows would be helpful to the economic growth is still in great popularity among policy makers and business leaders. But several insignificant data analysis results and various views motivate us to work on this issue continuously and in advance. Meantime, as for causality between these two variables, most of the previous literature mainly ignores this kind of issue. So this paper also explores the direction of causality between FDI inflows and GDP growth. And there is a possibility that previous results could be biased due to econometric problems such as endogeneity, omitted variables bias, etc. Fox example, the problem of omitted variables bias frequently appears in most previous literature because they use cross sectional data. Recently panel data analysis mitigates this problem but does not and could not eliminate it. It is well known that panel data technique can only reduce omitted variables from unmeasured or unobserved variables that are either constant over the time but varies across individuals or constant across individuals but varies over the time. This paper intends to reexamine the connection between FDI inflows and economic growth using times series technique and explore the long-run equilibrium relationship between these two variables.

In this paper, I employ time-series data from 1966 to 2005 for 5 countries to investigate the dynamics of foreign direct investment and economic growth. Specifically, this work finds ambiguous results about the growth effect of FDI but consistent significant FDI effect of growth for the 5 countries. The rest of the paper is organized as follows. Section 2 introduces data and methodology; Section 3 presents empirical results; Section 4 provides concluding remarks.

\section{DATA AND METHODOLOGY}

The sample includes five countries with the time period from 1966 to 2005: Australia (19662005), Canada (1966-2005), Israel (1966-2005), Austria (1967-2005) and Netherlands (19672005). The time series employed in the empirical analysis are GDP per capita in current US $\$^{3}$

\footnotetext{
2 Stock measure of FDI is formed as the ratio of nonbank employment in US affiliates of foreign firms to total employment in the state

${ }^{3}$ GDP at purchaser's prices is the sum of gross value added by all resident producers in the economy plus any product taxes and minus any subsidies not included in the value of the products. It is calculated without making
} 
and FDI net inflows per capita in current US\$4. The data on the two variables are from World Bank, World Development Indicators (2007).

As mentioned in the first section, the approach used for the empirical analysis is called EngleGranger (1987) bivariate cointegration procedure, which is employed to examine a long-run equilibrium relationship between two time series, that is, GDP per capita and FDI net inflows per capita in this paper. The main conception of this approach is that if two time series are respectively nonstationary, but a linear combination existing between them is stationary, then the two time series are cointegrated. If each time series is stationary originally, it is integrated of order zero, which is denoted as $I(0)$. If each time series is stationary in its first-order difference, it is integrated of order one, which is denoted as $I(1)$.

The procedure of this technique basically has three steps: (1) Unit root Test; (2) Conintegration Test; (3) ECM (Error Correction Model).

\section{Unit root test}

It is necessary to examine if either GDP per capital or FDI net inflows per capita is stationary, namely, to examine if either has a unit root. The test used in this paper is the Augmented Dickey - Fuller (ADF) unit root test. The main equation of this test is as follows:

$$
\begin{aligned}
& \Delta \mathrm{Y}_{\mathrm{t}}=a_{0}+\gamma_{1} * \mathrm{Y}_{\mathrm{t}-1}+a_{1}{ }^{*} \mathrm{t}+\sum a_{2 i} * \Delta \mathrm{Y}_{\mathrm{t}-\mathrm{i}}+\varepsilon_{1 \mathrm{t}} \\
& \Delta \mathrm{X}_{\mathrm{t}}=b_{0}+\gamma_{2} * \mathrm{X}_{\mathrm{t}-1}+b_{1} * \mathrm{t}+\sum b_{2 i} * \Delta \mathrm{X}_{\mathrm{t}-\mathrm{i}}+\varepsilon_{2 \mathrm{t}}
\end{aligned}
$$

Where $\Delta$ denotes the first difference operator; $\mathrm{t}$ is a linear time trend; $\varepsilon_{1 \mathrm{t}}$ and $\varepsilon_{2 \mathrm{t}}$ are stationary random error term. Both of the two equations are run by OLS estimation. In Equation (1), if $\gamma_{1}$ $=0$ is rejected, we conclude that the time series under consideration does not have a unit root. Otherwise, it indicates that the time series has a unit root. Likewise, in Equation (2), if $\gamma_{2}=0$ is rejected, the time series does not have a unit root. Then we should use ADF test again in $1^{\text {st }}$ difference. If both of the time series are nonstationary and are integrated of the same order, then we could use the cointegration test which is the second step of this approach.

\section{Cointegration test}

Cointegration regression in levels for the two time series is performed using simple equations below.

$$
\begin{aligned}
& \mathrm{Y}_{\mathrm{t}}=\alpha_{1}+\beta_{1} * \mathrm{X}_{\mathrm{t}}+\varphi_{1 \mathrm{t}} \\
& \mathrm{X}_{\mathrm{t}}=\alpha_{2}+\beta_{2} * \mathrm{Y}_{\mathrm{t}}+\varphi_{2 \mathrm{t}}
\end{aligned}
$$

Both equations are estimated by OLS. After the estimation, the residuals from Equations (3) and (4) are obtained for stationarity test by still using ADF unit root test. If the test results are that the residuals are stationary, we could conclude that these two time series are cointegrated

deductions for depreciation of fabricated assets or for depletion and degradation of natural resources. Data are in current U.S. dollars. Dollar figures for GDP are converted from domestic currencies using single year official exchange rates. For a few countries where the official exchange rate does not reflect the rate effectively applied to actual foreign exchange transactions, an alternative conversion factor is used.

${ }^{4}$ Foreign direct investment are the net inflows of investment to acquire a lasting management interest (10 percent or more of voting stock) in an enterprise operating in an economy other than that of the investor. It is the sum of equity capital, reinvestment of earnings, other long-term capital, and short-term capital as shown in the balance of payments. This series shows net inflows in the reporting economy. Data are in current U.S. dollars. 
and the linear combination between them is stationary. Then the following error correction model could be used to examine for the Granger causality.

$$
\begin{aligned}
& \Delta Y_{t}=c_{1}+\text { lagged }\left(\Delta Y_{t}, \Delta X_{t}\right)-\lambda_{1} \varphi_{1 t-1}+u_{1 t} \\
& \Delta X_{t}=c_{2}+\text { lagged }\left(\Delta X_{t}, \Delta Y_{t}\right)-\lambda_{2} \varphi_{2 t-1}+u_{2 t}
\end{aligned}
$$

From Equation (5), if the coefficients of lagged $\Delta X_{t}$ are jointly significant or the coefficient of lagged residual series -- $\lambda_{1}$ is significant, the null hypothesis that lagged $\Delta X_{t}$ does not Granger cause $\Delta Y_{t}$ is rejected, which implies that $\Delta X_{t}$ Granger causes $\Delta Y_{t}$, these two time series have a long-run equilibrium relationship. Likewise, from Equation (6), the null hypothesis that lagged $\Delta Y_{t}$ does not Granger cause $\Delta X_{t}$ is rejected if the coefficients of lagged $\Delta Y_{t}$ are jointly significant or $\lambda_{2}$ is significant. The lagged residual series, $\lambda_{1}$ and $\lambda_{2}$ from Equation (5) and (6) both have their particular role that they could help the time series which has departed from the other return to the long-run equilibrium relationship with the other time series.

\section{EMPIRICAL RESULTS}

As mentioned in section 2, the first step is to examine whether the two time series, GDP per capita and FDI net inflows per capita, have unit root. The test results are reported in Table 1. It can be seen that for each time series of the 5 countries, they are all nonstationary, indicating a unit root. FDI and GDP of each country are integrated of the same order, that is, order one I(1) since the ADF test p-values of the two time series in $1^{\text {st }}$ difference in Column (2) are all significantly different from zero.

Table 1. Unit root Test (ADF unit root test)

\begin{tabular}{cccc}
\hline \multirow{2}{*}{ Country } & \multirow{2}{*}{ Series } & \multicolumn{1}{c}{$(1)$} & \multicolumn{1}{c}{$(2)$} \\
& & Levels $(\mathrm{p}$-value) & $1^{\text {st }}$ difference (p-value) \\
\hline \multirow{2}{*}{ Australia } & FDI & 1.0000 & $0.0000^{* * *}$ \\
\cline { 2 - 4 } & GDP & 0.9795 & $0.0168^{* *}$ \\
\hline \multirow{2}{*}{ Canada } & FDI & 0.9999 & $0.0000^{* * *}$ \\
\cline { 2 - 4 } & GDP & 0.9923 & $0.0487^{* *}$ \\
\hline \multirow{2}{*}{ Israel } & FDI & 0.7720 & $0.0236^{* *}$ \\
\cline { 2 - 4 } & GDP & 0.9519 & $0.0003^{* * *}$ \\
\hline \multirow{2}{*}{ Austria } & FDI & 0.9874 & $0.0000^{* * *}$ \\
\cline { 2 - 4 } & GDP & 0.9866 & $0.0010^{* * *}$ \\
\hline \multirow{2}{*}{ Netherlands } & FDI & 0.6963 & $0.0001^{* * *}$ \\
\cline { 2 - 4 } & GDP & 0.9936 & $0.0010^{* * *}$ \\
\multirow{2}{*}{$* * *, * * *$ denote significance at $\mathbf{1 , 5}$ and 10\% confidence respectively. }
\end{tabular}

On the basis of results that each time series is nonstationary and integrated of order one, we proceed to perform Cointegration Test by estimating the following two equations using OLS:

$$
\begin{aligned}
& G D P_{t}=\alpha_{1}+\beta_{1} F D I_{t}+\varphi_{1 \mathrm{t}} \\
& F D I_{t}=\alpha_{2}+\beta_{2} G D P_{t}+\varphi_{2 \mathrm{t}}
\end{aligned}
$$


Table 2. Cointegration Tests

\begin{tabular}{ccc}
\hline \multirow{2}{*}{ Country } & \multicolumn{1}{c}{$(1)$} & \multicolumn{1}{c}{$(2)$} \\
& Cointegration Regression & Unit root test (p-value) \\
\hline \multirow{2}{*}{ Australia } & GDP $=9044.188+17.033^{*} \mathrm{FDI}$ & $0.0586^{*}$ \\
\cline { 2 - 3 } & $\mathrm{FDI}=-228.692+0.038^{*} \mathrm{GDP}$ & $0.0000^{* * *}$ \\
\hline \multirow{2}{*}{ Canada } & $\mathrm{GDP}=8842.929+19.455^{*} \mathrm{FDI}$ & $0.0373^{* *}$ \\
\cline { 2 - 3 } & $\mathrm{FDI}=-32.270+0.023^{*} \mathrm{GDP}$ & $0.0067^{* * *}$ \\
\hline \multirow{2}{*}{ Israel } & $\mathrm{GDP}=5801.139+21.905^{*} \mathrm{FDI}$ & $0.0317^{* *}$ \\
\cline { 2 - 3 } & $\mathrm{FDI}=-106.252+0.028^{*} \mathrm{GDP}$ & $0.0150^{* *}$ \\
\hline \multirow{2}{*}{ Austria } & $\mathrm{GDP}=9593.599+27.164^{*} \mathrm{FDI}$ & $0.0636^{*}$ \\
\cline { 2 - 3 } & $\mathrm{FDI}=-131.301+0.023^{*} \mathrm{GDP}$ & $0.0459^{* *}$ \\
\hline \multirow{2}{*}{ Netherlands } & $\mathrm{GDP}=10110.87+7.591^{*} \mathrm{FDI}$ & $0.0042^{* * *}$ \\
\cline { 2 - 3 } & $\mathrm{FDI}=-489.037+0.080^{*} \mathrm{GDP}$ & $0.0155^{* *}$ \\
\hline$* * * * * *$ deno
\end{tabular}

The regression results are shown in Table 2. The column (2) shows the ADF test p-values for the residuals coming from the cointegration regression. From these p-values, we can see that each of them is statistically significant. Such consistent results for these 5 countries imply that the residuals in both two above equations for each country are stationary. Generally speaking, it means that for each country, their GDP per capita and FDI net inflows have a linear combination with stationarity.

After obtaining the results of stationary residuals from the cointegration regression, the last step is do the error correction model regression for each of the 5 countries by employing the following empirical equations using OLS estimation:

$$
\begin{aligned}
& \Delta G D P_{t}=\mathrm{c}_{1}+\Sigma \theta_{1} \text { lagged } \Delta G D P_{t}+\Sigma \theta_{2} \text { lagged } \Delta F D I_{t}-\lambda_{1} \varphi_{1 t-1}+u_{1 t} \\
& \Delta F D I_{t}=c_{2}+\Sigma \eta_{1} \text { lagged } \Delta F D I_{t}+\Sigma \eta_{2} \text { lagged } \Delta G D P_{t}-\lambda_{2} \varphi_{2 t-1}+u_{2 t}
\end{aligned}
$$

Table 3. Error Correction Models (1)

\begin{tabular}{ccccccc}
\hline \multicolumn{6}{c}{$\Delta G D P_{t}=\mathrm{c}_{1}+\Sigma \theta_{1}$ lagged $\Delta G D P_{t}+\Sigma \theta_{2}$ lagged $\Delta F D I_{t}-\lambda_{1} \varphi_{1 t-1}+u_{1 t}$} \\
\hline \multirow{2}{*}{ Country } & \multirow{2}{*}{ Sample Period } & $(1)$ & $(2)$ & $(3)$ & $(4)$ & \multirow{2}{*}{ Lags } \\
& & $\Sigma \theta_{2}$ & $\Sigma \theta_{2}$ (p-value) & $\lambda_{1}$ & $\lambda_{1}$ (p-value) & \\
\hline Australia & $1966-2005$ & 7.618 & $0.0414^{* *}$ & 0.036 & 0.6336 & $(1,2)$ \\
\hline Canada & $1966-2005$ & -1.228 & 0.2951 & 0.004 & 0.8964 & $(1,1)$ \\
\hline Israel & $1966-2005$ & -1.416 & $0.0324^{* *}$ & 0.026 & 0.4905 & $(1,2)$ \\
\hline Austria & $1967-2005$ & -2.043 & 0.3377 & 0.047 & 0.3747 & $(1,1)$ \\
\hline Netherlands & $1967-2005$ & -2.402 & $0.0084^{* * *}$ & 0.026 & 0.6205 & $(1,2)$ \\
\hline
\end{tabular}

$* * *, * *, *$ denote significance at 1,5 and $10 \%$ confidence respectively.

The results are shown in Table 3 and Table 4. From both tables, it could be seen that they list the estimated coefficients and also the lags. The order of lags is based on Schwartz Information Criterion. Table 3 shows the results of the equation in which $\triangle G D P_{t}$ is the dependent variable. In this table, two values are particularly worth our attention: one is Column (2), listing the sum of estimated coefficients of lagged $\Delta F D I_{t}--\Sigma \theta_{2}$, the other one is Column (4), listing the estimated coefficient of lagged serial residuals -- $\lambda_{1}$, As for $\Sigma \theta_{2}$, the p-values are not all significant for these 5 countries. Among them, only for Australia, Israel and Netherlands, the p-values of $\Sigma \theta_{2}$ are statistically significant. So for these three countries, their FDI net inflows Granger causes their GDP growth. For the other two countries - Canada and Austria, the p-values of $\Sigma \theta_{2}$ are not 
significant. But if we could find significant $p$-values of $\lambda_{1}$ for these two countries, we could also conclude that their FDI net inflows Granger cause their GDP growth. However, unfortunately, when looking at the p-values of $\lambda_{1}$ for all of these 5 countries, none of them is significantly different from zero. So in short, we conclude that, on the FDI to GDP causality, only for Australia, Israel and Netherlands, their FDI net inflows Granger causes their GDP growth. However, for Canada and Austria, such causality does not exist.

Then for the second regression in which $\triangle F D I_{t}$ is the dependent variable, the results are shown in Table 4. In this table, it can be seen that in Column (2), the p-values of estimated coefficients of lagged $\Delta G D P_{t}-\Sigma \Sigma \eta_{2}$ are only significant for Australia, Canada and Israel, while for Austria and Netherlands, theirs are not significant. The estimated coefficient of lagged serial residuals -- $\lambda_{2}$ in Column (4) are significant for Austria and Netherlands. In sum, for all of these 5 countries, their GDP growth Granger causes their FDI net inflows.

Meanwhile, from Column (1) both in Table 3 and Table 4, focusing on the real values of the sum of coefficients for the lagged $\triangle F D I_{t}$ and lagged $\triangle G D P_{t}$ in the two equations respectively, we noted that the signs of the real values are various for different countries. Concerning the FDIGDP causality in the first equation, for Australia, the sign is positive, which implies that its FDI net inflows has a positive impact on their GDP growth. For Israel and Netherlands, on the other hand, the signs are negative indicating that their FDI net inflows does not have a positive impact on their GDP growth, that is, not beneficial for their GDP growth. For the GDP-FDI causality in the second equation, for Australia and Canada, the signs are positive, which indicates that the GDP growth in both countries is positively driving the FDI net inflows into their countries. By contrast, for the other three, Israel, Austria and Netherlands, the signs are negative, indicating that their GDP growth is not helpful for their FDI net inflows or even harmful and obstructive for their FDI net inflows.

\section{CONCLUDING REMARKS}

From the above empirical analysis on the GDP per capita and FDI net inflows per capita data of the 5 countries, this paper finds that not all of these countries have the same results on the relationship between GDP and FDI, that is, FDI inflows certainly is strongly positive for the economic growth and development. According to the estimation and analysis in this paper, it is indicated that Australia's FDI net inflows truly will promote this country's economic development. Canada and Austria do not have a significant impact from FDI net inflows on economic growth. For Israel and Netherlands, though they have significance of such relationship, the results are not optimistic. On the contrary, the FDI net inflows has a negative effect on their economic development. Such various results imply that the FDI to GDP relationship is still ambiguous. Whether FDI inflows boosts the economic growth and development still hasn't received a conclusive and definite result. The reason needs to be explored further in the future research.

But then, about the research on the causality from GDP to FDI, which has been mostly ignored by previous literature, has got some findings. Until now, we have found that for these 5 countries, their GDP-FDI inflows relationship are significant, which implies GDP-FDI has a longrun equilibrium relationship that the economic growth has a significant influence on the FDI inflows. Yet it is still difficult to draw a definite conclusion on whether such significance is positive or negative.

There are still some research work to be done in the future such as to analyze the detailed reasons for the different effects (positive or negative) and the conditions which cause the significant or insignificant relationship between GDP and FDI inflows. It is also valuable to 
compare the results among different countries. Furthermore, in this paper, the sample is from 1966 to 2005 which is not a long time period, which may be the reason of ambiguous results of the growth effect of FDI. Therefore, it is of concern to do the future research on this topic by using data with a longer time period if they are available.

\section{References}

Alexiou, Constantinos and Tsaliki, Persefoni V. (2007) Foreign Direct Investment-Led Growth Hypothesis: Evidence from the Greek Economy, Zagreb International Review of Economics and Business, 10, 85-97.

Alfaro, L; Chanda, A and Kalemli-Ozcan, S, et al. (2004) FDI and economic growth: the role of local financial markets, Journal of International Economics, 64, 89-112.

Alfaro, L. (2003) Foreign Direct Investment and Growth: Does the Sector Matter? mimeo, Harvard Business School.

Balasubramanyam, V. N. and Salisu, M. and Sapsford, D. (1996) Foreign Direct Investment and Growth in EP and IS Countries, Economic Journal, 106, 92-105.

Baliamoune-Lutz, Mina N. (2004) Does FDI Contribute to Economic Growth? Business Economics, 39, 49-56.

Basu, Parantap and Guariglia, Alessandra (2007) Foreign Direct Investment, Inequality, and Growth, Journal of Macroeconomics, 29, 824-39.

Bende-Nabende, Anthony; Ford, Jim and Slater, Jim (2001) FDI, Regional Economic Integration and Endogenous Growth: Some Evidence from Southeast Asia, Pacific Economic Review, 6, 383-99.

Bende-Nabende, A. and Ford, J. L. (1998) FDI, Policy Adjustment and Endogenous Growth: Multiplier Effects from a Small Dynamic Model for Taiwan, 1959-1995, World Development, 26, 1315-30.

Blonigen, B.A. and Wang, M. (2004) Inappropriate Pooling of Wealthy and Poor Countries in Empirical Studies, NBER Working Paper No: 10378.

Borensztein, E.; Gregorio, J. and Lee, J. (1998) How Does Foreign Direct Investment Affect Economic Growth, Journal of International Economics, 45, 115-135.

Buckley, Peter J._et al. (2002) FDI, Regional Differences and Economic Growth: Panel Data Evidence from China, Transnational Corporations, 11, 1-28.

Carkovic, M. and Levine, R. (2002) Does Foreign Direct Investment Accelerate Economic Growth? mimeo, Finance Department, University of Minnesota.

De Gregorio, J. (1992) Economic Growth in Latin America, Journal of Development Economics, 39, 59-83.

Dhakal, Dharmendra; Rahman, Saif and Upadhyaya, Kamal P. (2007) Foreign Direct Investment and Economic Growth in Asia, Indian Journal of Economics and Business, 6, 15-26.

Ford, Timothy C.; Rork, Jonathan C. and Elmslie, Bruce T. (2008) Foreign Direct Investment, Economic Growth, and the Human Capital Threshold: Evidence from US States, Review of International Economics, 16, 96-113.

Kevin Honglin (1999) How Does FDI Interact with Economic Growth in a Large Developing Country? The Case of China, Economic Systems, 23, 291-303.

Lipsey, Robert E. (2000) Inward FDI and Economic Growth in Developing Countries, Transnational Corporations, 9, 67-95.

Luo, Changyuan (2007) FDI, Domestic Capital and Economic Growth: Evidence from Panel Data at China's Provincial Level, Frontiers of Economics in China, 2, 92-113.

Mohan, Ramesh (2007) A Panel Data Analysis of FDI, Trade Openness, and Liberalization on Economic Growth of the ASEAN-5, Empirical Economics Letters, 6, 35-44.

Naveed, Amjad and Shabbir, Ghulam (2006) Trade Openness, FDI and Economic Growth: A Panel Study, Pakistan Economic and Social Review, 44, 137-54.

Nunnenkamp, Peter and Spatz, Julius (2004) FDI and Economic Growth in Developing Economies: How Relevant Are Host-Economy and Industry Characteristics? Transnational Corporations, 13, 53-86.

Olomola and Philip Akanni (2004) The FDI-Growth Hypothesis: A VAR Model for Nigeria, South African Journal of Economic and Management Sciences, 7, 171-85.

Qi, Liangshu (2007) The Relationship between Growth, Total Investment and Inward FDI: Evidence from Time Series Data, International Review of Applied Economics, 21, 119-33. 
Saltz, Ira S. (1992) The Negative Correlation between Foreign Direct Investment and Economic Growth in the Third World: Theory and Evidence, Rivista Internazionale di Scienze Economiche e Commerciali, 39, 617-33.

Trevino, Len J. and Upadhyaya, Kamal P. (2003) Foreign Aid, FDI and Economic Growth: Evidence from Asian Countries, Transnational Corporations, 12, 119-35.

Vu, Tam; Gangnes, Byron and Noy, Ilan (2008) Is Foreign Direct Investment Good for Growth? Evidence from Sectoral Analysis of China and Vietnam, University of Hawaii at Manoa, Department of Economics, Working Papers: 200801.

Whalley, John and Xin, Xian (2006) China's FDI and Non-FDI Economies and the Sustainability of Future High Chinese Growth, National Bureau of Economic Research, Inc, NBER Working Papers: 12249.

Yao, SJ (2006) On Economic Growth, FDI and Exports in China, Applied Economics, 38, 339-351. 